\title{
AKTYWNE FORMY WITAMINY D A ZDROWIE
}

\author{
ACTIVE FORMS OF VITAMIN D AND HEALTH \\ Anna Małgorzata Piotrowska', Olga Czerwińska-Ledwig', Adam Podhorecki², Wanda Pilch' \\ 'Zakład Biochemii i Podstaw Kosmetologii, Katedra Kosmetologii, Wydział Rehabilitacji Ruchowej, AWF w Krakowie \\ ${ }^{2}$ Oddział Kliniczny Ortopedii i Rehabilitacji, Szpital Uniwersytecki w Krakowie
}

DOI: https://doi.org/10.20883/ppnoz.2019.68

\section{STRESZCZENIE}

Witamina D została odkryta w 1922 r. Jest to substancja o wielokierunkowym działaniu na organizm człowieka, wykazująca wiele cech hormonu. Wewnątrzkomórkowy receptor tej witaminy znajduje się w komórkach większości tkanek organizmu, co odpowiada za skutki jej działania oparte o regulację ekspresji genów. Dostarczanie tej witaminy do organizmu zachodzi zarówno na drodze podaży w diecie, jak również z ekspozycji na promieniowanie UV, która prowadzi do jej syntezy w skórze. Niedobór witaminy D stanowi bardzo powszechne zjawisko w populacji europejskiej. W niniejszej pracy dokonano przekrojowej analizy wpływu witaminy D na poszczególne układy organizmu ludzkiego. Omówiono procesy fizjologiczne związane z jej produkcją, metabolizmem, skutki niedoboru i nadmiaru, metody analityczne wykorzystywane do pomiaru stężenia metabolitów tej witaminy w surowicy krwi. Opisano również rolę witaminy D w patogenezie różnych jednostek chorobowych oraz w okresie ciąży.

Słowa kluczowe: witamina D, działanie plejotropowe, kalcitriol, hipowitaminoza.

ABSTRACT

Vitamin D was discovered in 1922. It is a substance which has multi-directional effects on human body and has many properties of a hormone. Intracellular receptor of this vitamin is found in the cells in majority of tissues in human body, and is responsible for the effects of its action based on the regulation of gene expression. The supply of this vitamin is associated with dietary intake, as well as the exposure to UV radiation, which leads to its synthesis in the skin. Vitamin D deficiency is very common in the European population. This paper presents a cross-sectional analysis of the effects of vitamin D on human body systems. Physiological processes related to its production, metabolism, the effects of deficiency and excess, analytical methods used to measure the concentration of metabolites of this vitamin in blood serum were discussed. The role of vitamin $D$ in the pathogenesis of various diseases and during pregnancy has also been described.

Keywords: vitamin D, pleiotropic action, calcitriol, hipovitaminosis.

\section{Wstęp}

Choć pierwsze wzmianki pojawiały się już wprawdzie w XVII W., witamina D została odkryta dopiero w $1922 \mathrm{r}$. Była to czwarta odkryta witamina, stąd otrzymała nazwą wynikającą z kolejności alfabetycznej. Pierwotnie kojarzona była przede wszystkim z rozległym wpływem na układ kostny i gospodarkę fosforanowo-wapniową organizmu człowieka [1]. Kolejne badania wykazały jednak, iż witamina D posiada wiele cech hormonu. Aktywna forma tego związku znajduje się w licznych tkankach w stężeniach typowych dla hormonów [2], a obecność jądrowych receptorów dla witaminy D (ang. Vitamin D Receptor VDR) potwierdzono między innymi w miocytach, komórkach beta trzustki oraz neuronach [2].

Już w 1822 r. Jędrzej Śniadecki postulował zależności pomiędzy kąpielami słonecznymi a leczeniem krzywicy. W 1936 r. odkryto w skórze człowieka obecność 7-dechydroksycholesterolu, który pod wpływem promieniowania UV ulega izomeryzacji i przechodzi w cholekalcyferol (witaminę D3). Kolejne dekady niosły przełomowe odkrycia. Potwierdzono, że jest to hormon steroidowy o masie cząsteczkowej 55kDa z grupy 9,10-sekosterydów, a wpływ na komórki docelowe odbywa się poprzez receptor wewnątrzkomórkowy. Działanie wiąże się z prawidłową pracą mitochondriów oraz odpowiednią regulacją procesów związanych z powstawaniem wolnych rodników tlenowych [3].

Celem pracy była analiza wpływu witaminy D na poszczególne układy organizmu człowieka. Przedstawiono farmakokinetykę tej witaminy, skutki nadmiaru i niedoboru w diecie. Autorzy starali się wyłuszczyć objawy wskazujące na konieczność zwiększonej podaży w diecie lub stosowanie suplementacji.

\section{Wyniki}

Podaż i dostarczanie witaminy D

Źródła tej witaminy u człowieka mogą być dwojakie: dzięki syntezie skórnej pod wpływem promieniowania słonecznego lub absorpcji jelitowej z pokarmu. W przy- 
rodzie odkryto dwa związki, które po szeregu przemianach chemicznych wykazują aktywność witaminy D. Jest to cholekalcyferol (witamina D3) związek pochodzenia zwierzęcego o masie cząsteczkowej 384,6 Da (9,10-sekocholesta-5,7,10(19)-trien-3beta-ol) oraz występująca w drożdżach i grzybach witamina D2 (ergokalcyferol) o masie cząsteczkowej 396,7 Da (9,10-sekoergosta5,7,10(19)22,23-tetraen-3beta-ol). Znakomita większość produktów spożywczych nie zawiera bądź zawiera jedynie niewielkie ilości tej witaminy, dlatego też nie jest możliwe pokrycie zapotrzebowania organizmu wyłącznie drogą pokarmową. Na chwilę obecną przyjęte jest, iz w ciągu doby powinno się dostarczać wraz z dietą średnio 1000-4000 IU witaminy D. Względnie bogatym jej źródłem są ryby morskie (šledź, łosoś, węgorz, sardynki), które pobierają ją z niektórych odmian planktonu. Podczas obróbki cieplnej minimum połowa zawartości jest niszczona (utrata dochodzi nawet do 95\%) [4]. Dobrym źródłem witaminy $D$ jest tran, jednakże jest on także źródłem witaminy A, której nadmiar może prowadzić do zatrucia, działa również teratogennie [5]. Zawartość witaminy D w mleku, jajach i mięsie w dużej mierze zależy od tego, ile czasu dane zwierzę przebywało na słońcu, oraz jej podaży z karmą (obecnie dodaje się około 50 $100 \mathrm{IU} / 100 \mathrm{~g}$, czyli bardzo niewiele). Źródłem witaminy D

344 w diecie wegetariańskiej i wegańskiej jest awokado (zawiera 140-200 IU/100 g) oraz grzyby (pieczarki 80 IU/100 g, prawdziwki $120 \mathrm{IU} / 100 \mathrm{~g}$ ).

Witamina D rozpuszcza się w tłuszczach i dzięki obecności soli żółciowych powstają układy miceralne pomagające $w$ procesie trawienia i wchłaniania. Dysfunkcje prowadzące do obniżonej produkcji soku trzustkowego zaburzają te procesy. Podobny efekt wykazuje nadmiar lipidów w diecie (witamina pozostaje wówczas w micelach i nie dyfunduje przez błony komórkowe). Po wchłonięciu zostaje ona włączona do chylomikronów i jest transportowana układem limfatycznym.

\section{Bezpieczna suplementacja}

Zapotrzebowanie zmienia się wraz z wiekiem oraz, zwłaszcza dla stref o sezonowych zmianach usłonecznienia, z porą roku. Osoby zdrowe powinny suplementować witaminę D w celach profilaktycznych, zwłaszcza w okresie od września do kwietnia $[6,7]$. Obowiązkową suplementację należy uwzględnić w diecie noworodków, które do 6 miesiąca życia nie powinny być poddawane zbyt intensywnej ekspozycji na promieniowanie UV. Uwagę należy także zwracać na seniorów (po 65 r.ż. zdolność do syntezy skórnej jest znacznie zmniejszona). Najczęściej niedobory spotkać można u dorosłych pacjentów leczonych szpitalnie
(57\%), seniorów w domach opieki (25-50\%), pacjentek powyżej 80 r.ż. (44\%) oraz dorosłych Afroamerykanów (42\%) [8].

W suplementacji dopuszczalne jest przyjmowanie cholekalcyferolu (witamina D3), ergokalcyferolu (witamina D2) bądź też kalcyfediolu (tylko w przypadkach kiedy hydroksylacja wątrobowa nie jest w pełni skuteczna). Działanie witaminy D2 jest o 30\% słabsze niż działanie witaminy D3. Przyjmowanie w suplementacji alfakalcydiolu czy kalcytriolu nie jest wskazane [9]. Witamina D ma dług okres półtrwania i nie zaleca się przyjmowania suplementów codziennie. Odstępy między przyjmowanymi dawkami powinny jednak być zbliżone lub (najlepiej) takie same. Dawka przyjęta jednorazowo nie może przekraczać 6000 IU [10]. Według EFSA (European Food Safety Authority) suplementacją bezpieczną jest dawka 4000 j.m. na dobę Wyjątkiem są osoby z zaburzeniami wchłaniania lub otytością (indywidualnie dobrana dawka może wzrosnąć do 10000 IU na dobę) [11, 12]. Dostępne w Polsce preparaty z tą witaminą zawierają od 500 do 4000 IU (tabletki i kapsułki), dawka preparatów dla niemowląt ordynowanych w kroplach wynosi $0,5 \mathrm{mg} / \mathrm{ml}(20000 \mathrm{IU} / \mathrm{ml})$. W suplementach diety dawki są przeważnie niższe.

\section{Oznaczanie poziomu witaminy D w organizmie człowieka i wartości prawidłowe}

Istnieje wiele metod oznaczania poziomu witaminy $D$ i jej metabolitów we krwi. Przyjęto, że ogólny poziom w organizmie najlepiej odzwierciedla poziom kalcydiolu, ponieważ nie podlega on mechanizmom regulującym. Określenie stężenia umożliwia ocenę stanu zaopatrzenia organizmu w witaminę D pochodzącą zarówno z diety, jak i syntezy skórnej.

Jako pierwsze, w rutynowej metodzie oznaczania stężenia witaminy D w surowicy, używano metody izotopowe i radioizotopowe (RIA, ang. radioimmunoassay), następnie wprowadzono metodę wysokosprawnej chromatografii cieczowej (HPLC, ang. high-performance liquid chromatography) [13]. Obecnie najczęściej używane są metody immunochemiczne, zwłaszcza z detekcją chemiluminescencj (CLIA, ang. chemiluminescent immunoassay) oraz metoda immunoenzymatyczna (EIA, ang. enzyme immunoassay) [14]. Wyniki międzylaboratoryjnej kontroli jakości dla tych metod są niekiedy mało satysfakcjonujące [15], co wynikać może z niespecyficznych i trudnych do przewidzenia interferencji [13]. Z tego względu coraz częściej stosuje się metodę LC-MS/MS (ang. liquid chromatography with mass spectrometry, chromatografia cieczowa ze spektrometrią mas), która jest równocześnie metodą referencyjną [15] Znane są także inne metody chromatograficzne, takie jak 
wspomniana już chromatografia HPLC, która uznawana jest obecnie za „złoty standard” [14], czy gazowa sprzężona ze spektrometrią mas GC-MS (ang. gas chromatography - mass spectrometry). Metody te ze względu na poziom technologicznego skomplikowania, często pracochłonny proces przygotwania próbki do oznaczenia (HPLC) lub konieczność przeprowadzania badanego związku w lotne pochodne (GC-MS), stosowane są głównie w projektach naukowych, a nie w laboratoriach analitycznych dostępnych dla pacjentów [14, 15]. W porównaniu metod CLIA i EIA najlepszą korelację z metodą HPLC uzyskano dla wyników CLIA, co według autorów badania wskazuje, iż CLIA jest dobrą metodą oznaczania poziomu witaminy $D$ do rutynowych oznaczeń laboratoryjnych [14].

Do wykrycia niektórych chorób lub zaburzeń konieczne jest oznaczenie poziomu 1,25(OH)2D zamiast 25(OH)D lub obu wymienionych związków. U pacjentów z niewydolnością nerek filtracja kłębuszkowa zostaje zmniejszona, co upośledza produkcję 1-alfa-hydroksylazy, w wyniku czego spada stężenie 1,25(OH)2D, a poziom 25(OH)D znacznie wzrasta. Sytuacja przeciwna występuje u pacjentów z sarkoidozą i gruźlików [16, 17].

Prawidłowe stężenie w osoczu wynosi 30-100 ng/ml. Przy stężeniu powyżej $150 \mathrm{ng} / \mathrm{ml}$ istnieje ryzyko wystąpienia zbyt wysokiego poziomu wapnia, a działanie toksyczne witaminy D pojawia się przy $300 \mathrm{ng} / \mathrm{ml}$. Niedobór wywołujący ryzyko osteoporozy w wieku starszym wiąże się ze stężeniemmi poniżej $30 \mathrm{ng} / \mathrm{ml}$. Znaczny niedobór zaburzający pracę wegetatywnego systemu nerwowego to $20 \mathrm{ng} / \mathrm{ml}$, ekstremalny niedobór to wszystkie wartości poniżej $12 \mathrm{ng} / \mathrm{ml}$ [15].

\section{Objawy niedoboru witaminy D}

Szacuje się, że niedobory witaminy D występują u blisko 1 miliarda ludzi na całym świecie, w Europie zjawisko to jest szczególnie częste [18]. Są to przede wszystkim osoby starsze, które zamieszkują obszary zurbanizowane, lecz problem dotyczy także dzieci i osób młodych, nawet w krajach o usłoniecznieniu znacznie wyższym niż w Polsce [19]. Według badań przeprowadzonych w 2014 r. w dziesięciu miastach Polski w okresie zimowym (przełom lutego i marca) z grupy 2,5 tysiąca osób dorosłych zaledwie $8,4 \%$ miało prawidłowe stężenia witaminy D. Ponad $90 \%$ osób zostało zakwalifikowanych jako osoby z niedoborem, co oznacza, że Polska jest krajem, gdzie na poziomie epidemiologicznym niedobór witaminy $\mathrm{D}$ jest znacznym problemem [20].

Wśród czynników ryzyka wystąpienia hipowitaminozy wymienia się uwarunkowania prowadzące do obniżonej podaży (źle skomponowana dieta, niedożywienie, niska ekspozycja na promieniowanie słoneczne), czynniki wynikające z chorób przewodu pokarmowego prowadzące do zaburzeń wchłaniania (choroby zapalne jelit i trzustki, zespół krótkiego jelita, stan po operacjach bariatrycznych), dysfunkcje czynnościowe wątroby i nerek [8]. Hipowitaminoza może także być konsekwencją stosowanej farmakoterapii (działanie udokumentowane $w$ tym kierunku mają niektóre leki przeciwpadaczkowe [21]).

Typowe objawy niedoboru witamy D zostały podzielone na pięć grup tworzących akronim: M-A-N-O-S [22]. Związane z układem mięśniowym (muskulatura - M): ograniczenie dopływu wapnia do miocytów, szczególnie w godzinach nocnych skutkuje drganiem, skurczami, wzrostem napięcia mięśniowego, bólem i osłabieniem mięśni. Związane z ogólnym samopoczuciem (adynamia - A): wyczerpanie, przygnębienie, zespół przewlekłego zmęczenia. Związane z układem nerwowym (system nerwowy - N): bezsenność, znużenie, zaburzenia koncentracji i depresja. Związane z układem krążenia (ortostatyka - 0): wrażliwość na chłód, drętwieniem kończyn, ból i zawroty głowy (hipotonia ortostatyczna). Związane z układem kostnym (szkielet - S): osteoporoza lub osteomalacja.

\section{Hiperwitaminoza}

Wewnętrzna regulacja stężenia działająca na zasadzie sprzężenia zwrotnego sprawia, że bardzo trudno jest osiągnąc zbyt wysoki poziom witaminy $D$ w wyniku ekspozycji na światło słoneczne. Praktycznie nie istnieje ryzyko przedawkowania, nawet jeżeli ekspozycja na słońce była zbyt długa. Podczas biosyntezy wytwarzane są równoczasowo nieaktywne metabolity witaminy $D$ (tachysterol, przy promieniowaniu o długości 260 nm i lumisterol, powstający przy promieniowaniu o długości fali $310 \mathrm{~nm}$ ) [23]. Synteza skórna jest też ograniczana fotolizą produktu [24]. Wystąpienie hiperwitaminozy związane jest przede wszystkim z nadmiernym spożywaniem niezwykle modnych obecnie suplementów diety. Objawy to przede wszystkim: hiperkalcemia, kalcyfikacja narządów (w szczególności nerek, co skutkuje ich trwałym uszkodzeniem) i naczyń krwionośnych. Wyróżnia się również objawy, takie jak utrata apetytu, zaburzenia rytmu serca czy wapnienie tkanek miękkich, wzrost ilości fosforu i wapnia w moczu.

\section{Synteza skórna witaminy D}

Prowitamina D (7-dehydrocholesterol) gromadzi się w błonach komórkowych keratynocytów warstwy podstawnej i kolczystej naskórka, a także w fibroblastach skóry właściwej. Dzięki promieniowaniu o długość fali 290-315 nm możliwa jest synteza skórna po upływie 30 minut ekspo- 
zycji, pod warunkiem, że skóra osiągnie temperaturę minimum $25^{\circ} \mathrm{C}$ [25]. Proces zachodzi nawet do kilku dni po zakończeniu ekspozycji. W Polsce taki ciąg reakcji skórnych możliwy jest tylko od kwietnia do września (promieniowanie słoneczne pada wtedy pod kątem większym niż 30 stopni). Najintensywniejszą syntezę witaminy D odnotowuje się w efekcie ekspozycji w południe, ponieważ stosunek ilości promieniowania UVB do promieniowania UVA jest najwyższy. Ekspozycji podlegać musi przynajmniej $18 \%$ powierzchni ciała. Czynnikami osobniczymi wpływającym na aktywność syntezy skórnej są: fototyp i pigmentacja, wiek i BMI (zwłaszcza znaczna ilość tkanki tłuszczowej, która poprzez produkcję leptyny upośledza efektywną biosyntezę skórną) [26]. Powstała witamina D przyłącza się do białka DBP (Vitamin D-Binding Protein) i dalej transportowana jest w układzie krwionośnym. Przemieszcza się do wątroby, gdzie jest hydroksylowana do 25 hydroksywitaminyę D (25(OH)D, kalcydiol), kolejne etapy jej metabolizmu zachodzą w nerkach. Ulega 1-hydroksylacji (powstaje kalcytriol, 1,25-dihydroksywitamina D), a następnie kolejnej hydroksylacji przy 24-tym atomie węgla. Nowe badania udowadniają, że 1-hydroksylacja odbywa się także w innych komórkach - makrofagach, keratynocytach, w łożysku, przytarczycach czy mięśniówce gładkiej. Do powyższej listy zaliczyć można także komórki nowotworowe [27].

\section{Witamina D a układ immunologiczny}

Najważniejszym skutkiem działania witaminy D na układ odpornościowy człowieka jest wygaszanie reakcji zapalnych, co chroni przed stanem długotrwałego, przewlekłego stanu zapalnego i chorobami z autoagresji. Receptor witaminy $\mathrm{D}(\mathrm{VDR}$, ang. Vitamin $\mathrm{D}$ receptor) jest obecny w wielu komórkach układu odpornościowego, takich jak aktywowane limfocyty T i B, neurofile, makrofagi, a także komórki dendrytyczne. Dzięki temu kalcytriol ma działanie immunomodulujące w odpowiedzi swoistej i nieswoistej [28]. Obniża poziom cytokin prozapalnych, ilość limfocytów pomocniczych (Th, T-helper) przy równoczesnym wzroście ilości cytokin przeciwzapalnych. Pobudza obronę przeciwbakteryjną wpływając na neutrofile, monocyty oraz komórki NK [29]. Zapobiega odrzuceniu przeszczepu, nie zwiększając przy tym podatności na infekcje wirusowe i grzybicze [30].

Badana jest rola witaminy D w przebiegu chorób dermatologicznych o podłożu autoimmunizacyjnym. Badania Morimoto [31] potwierdzone dużymi badaniami klinicznymi [32] wskazały, że zmiany łuszczycowe u pacjenta z osteoporozą ustąiłły po leczeniu kalcytriolem, doprowadziło to do wprowadzenia do lekospisów nowej grupy leków (kalcypotriol i takalcytol).
Witamina D indukuje ekspresję cytokiny TSLP (ang Thymic stromal lymphopoietin), która jest kluczowym czynnikiem w inicjacji ekspresji fenotypu AZS, ponadto kalcytriol powoduje zwiększenie populacji limfocytów regulatorowych (Treg), które mają zdolność hamowania skórnych reakcji alergicznych [11], a w keratynocytach występuje enzym CYP27B1, dzięki któremu kalcytriol metabolizowany jest do formy aktywnej 1,25(OH)D zdolnej do hamowania bądź stymulowania różnicowania keratynocytów. Kalciytriol ma swój udział w syntezie białka filagryny, która buduje warstwę rogową naskórka [33]. Działanie potwierdzono w badaniach klinicznych z suplementacją witaminą $\mathrm{D} u$ atopowych pacjentów [34].

Schorzeniem o podłożu autoimmunologicznym, z którym związana jest witamina D i może być wykorzystywana w jego terapii, jest stwardnienie rozsiane (SM, sclerosis multiplex). Jej rola wiąże się z modulacją działania układu odpornościowego [35]. W badaniach, w których wzięło udział 35794 kobiet, udowodniono, że przy suplementacji witaminą D w trakcie ciąży znacznie obniżało się ryzyko wystąpienia SM u potomstwa [36]. W pracy z $2012 \mathrm{r}$. wskazano, że dodanie jej do terapii interferonem zmniejsza nasilenie choroby [37].

Znaczny deficyt witaminy $D$ w organizmie stwierdza się u osób chorujących na reumatoidalne zapalenie stawów (RZS) [38]. W przebiegu tej choroby witamina D działa przede wszystkim ochronnie na komórki tkanki chrzęstnej i kostnej, zmniejszając stan zapalny i sprawia, że przebieg choroby jest mniej ciężki. Ponadto minimalizuje ryzyko uszkodzenia tkanki chrzęstnej i kostnej [39]. Suplementacja w przebiegu chorób reumatoidalnych była już skutecznie badana klinicznie, a poziom witaminy korelował ujemnie ze stadium zaawansowania choroby $[40,41]$.

\section{Witamina D a układ oddechowy}

Kompleks kalcytriol VDR jest głównym czynnikiem transkrypcyjnym dla katelicydyny i defensyny, wpływając $w$ ten sposób na stan układu oddechowego człowieka [42]. Aktywacja receptorów TLR1 i TLR2 (ang. Toll-like receptor-1, -2) na makrofagach i monocytach zapoczątkowuje szereg reakcji zależnych od witaminy $D$.

Witamina D ma znaczenie w ochronie przed chorobami zakaźnymi, a w szczególności przed gruźlicą. Przy bardzo niskim stężeniu witaminy D w surowicy krwi (nie więcej niż $50 \mathrm{nmol} / \mathrm{l})$ makrofagi i monocyty nie mogą aktywować wrodzonej odpowiedzi immunologicznej organizmu. Nasilająca się hipowitaminoza predysponuje do rozwoju gruźlicy, a także sprawia, że jej przebieg jest dużo cięższy [43].

Kolejnym schorzeniem, w którym badania udowadniają wyraźny związek między poziomem witaminy $D$ 
w surowicy a ryzykiem i częstotliwością występowania, a także ciężkością przebiegu, jest astma [44]. Potwierdzony jest również związek pomiędzy poziomem witaminy $D$ w surowicy a skutecznością wziewnej terapii glikokortykosteroidami. Osoby utrzymujące optymalny poziom witaminy D wykazują większą odpowiedź, co obserwowano nawet u pacjentów opornych na wcześniejszą steroidoterapię [45].

Zauważono również, że u osób chorujących na przewlekłą obturacyjną chorobę płuc (POChP) infekcje układu oddechowego występują częściej przy obniżonym poziomie witaminy D [46]. Podobne wnioski wysunięto dla pacjentów z mukowiscydozą (obniżony poziom defensyn i katelicydyn) [47]. Jednym ze skutków mukowiscydozy jest niewydolność trzustki, co wiąże się z upośledzeniem wchłaniania tłuszczów i witamin w nich rozpuszczonych, w tym witaminy $D$. Skutkuje to pogorszeniem procesu mineralizacji kości oraz ogólnym pogorszeniem stanu gospodarki wapniowej organizmu. W badaniach przeprowadzonych przez Grey'a wśród dzieci chorujących na mukowiscydozę aż 70\% miało obniżoną gęstość kości [48].

\section{Witamina D a układ pokarmowy i otyłość}

Witamina D wchłaniana jest w jelicie czczym, a także w końcowym odcinku jelita krętego. Grupą schorzeń układu pokarmowego, w którym obserwuje się niedobór witaminy $D$, są nieswoiste choroby zapalne jelit. U pacjentów z czasem rozwija się osteoporoza i osteopenia. Obniżone stężenie kalcydiolu obserwuje się również w przypadku niealkoholowego stłuszczania wątroby oraz $u$ chorych z dysfunkcją produkcji soli zółciowych [49, 50].

Potwierdzono, że witamina D ma związek z otyłością. Tkanka tłuszczowa od dawna jest uważana za główne miejsce jej magazynowania. Częstość współwystępowania hipowitaminozy i otyłości tłumaczy się poprzez wpływ kalcydiolu na PTH (parathormon): niski poziom witaminy D skutkuje wzrostem stężenia PTH, co z kolei powoduje wtórną nadczynność przytarczyc. Wzrost napływu wapnia do komórek tłuszczowych powoduje przyrost masy ciała [51]. Poznawane są molekularne podstawy powiązania witaminy $\mathrm{D}$ z metabolizmem tkanki tłuszczowej. VDR i enzymy metabolizujące witaminę D ulegają ekspresji w adipocytach [52], witamina ta reguluje ekspresję genu adipogennego, jak również apoptozę adipocytów [53]. Jest w nich aktywna na wszystkich poziomach metabolizmu. Oddziałuje z receptorami błonowymi, cząsteczkami adapterów i białkami jądrowymi. Uczestniczy w regulacji metabolizmu energetycznego poprzez kontrolę ekspresji białek rozprzęgających. In vitro witamina D stymuluje lipogenezę i hamuje lipolizę. Ponadto wpływa bezpośrednio na ekspresję hormonu regulującego apetyt, leptyny [54].
Podejrzewa się także, że reguluje ekspresję adiponektyny uwrażliwiającej komórki na działanie insuliny. Witamina D zmniejsza uwalnianie cytokin, wygasza przewlekły stan zapalny tkanki tłuszczowej poprzez hamowanie sygnalizacji NF-KB (ang. nuclear factor kappa-light-chain-enhancer of activated $B$ cells). Otyłość w ogromnej większości przypadków wiąże się z niedoborem witaminy D [55]. Suplementacja tej witaminy nie prowadzi jednak do utraty wagi u osób otyłych [53].

\section{Witamina $\mathrm{D}$ a układ sercowo-naczyniowy}

Udowodniono, że witamina D ma wpływ na etiopatogenezę wielu chorób sercowo-naczyniowych [56]. Receptor VDR, a także enzym 1 $\alpha$-hydroksylaza zlokalizowano w m.in. w miocytach i fibroblastach serca, komórkach mięśniówki gładkiej naczyń krwionośnych oraz w komórkach śródbłonka [57, 58]. Wskazuje się także w modelu zwierzęcym, że zarówno wysokie, jak i niskie stężenia aktywnych metabolitów witaminy D mogą wpływać na poziom ciśnienia krwi $[59,60]$. Jednak związek ten wymaga przeprowadzenia dalszych badań.

Witamina D wpływa na aktywność układu reninaangiotensyna-aldosteron, hamując ekspresję genu dla reniny [61]. Udowodniono także zależność między niskim stężeniem kalcytriolu a wysokim poziomem reniny, co powoduje znaczne podwyższenie ciśnienia tętniczego [62]. W badaniach przeprowadzonych przez Kienreicha potwierdzono znaczny wzrost ekspresji reniny u myszy pozbawionych genu kodującego receptor VDR. Ponadto wskazano, że chorowały one również na nadciśnienie tętnicze i hipertrofię mięśnia sercowego [63]. Podobne badania przeprowadził Pilz i doszedł do tych samych wniosków [64].

Witamina D ma udokumentowany wpływ na układ krzepnięcia. Kalcytriol ma działanie przeciwkrzepliwe [65]. W badaniach klinicznych wskazano związek deficytu aktywnych metabolitów witaminy D z zakrzepicą żył głębokich [66].

\section{Witamina D a układ nerwowy}

Receptory VDR obecne są w ośrodkowym i obwodowym układzie nerwowym. Komórki Purkiniego i neurony zlokalizowane w korze mózgowej oraz hipokampie wykazują powinowactwo do witaminy D. Przyczynia się ona do zwiększenia produkcji neurotransmiterów, w szczególności dopaminy, co może być powiązane z etiopatogenezą choroby Parkinsona [67], zespołem niespokojnych nóg [68], zwiększoną tendencją do psychogennej otyłości i zależności lekowych [69]. Ponadto przy znacznym deficycie potwierdzono większą częstotliwość występowania zaburzeń funkcji poznawczych, w tym także choroby Alzhe- 
imera [70]. Istnieje wiele doniesień mówiących, że niedobór witaminy D ma związek z depresją. Udowodniono to między innymi w czasie 3-letniej obserwacji kobiet w projekcie Women's Health Initiative (WHI, https://www.whi. org). Pacjentki były bardziej podatne na depresję, kiedy dzienna dawka witaminy D wynosiła mniej niż 400 IU [71]. Wskazuje się dużą jej rolę w prewencji depresji poporodowej oraz stanów lękowych w czasie trwania ciąży [72].

\section{Witamina $D$ a ciąża}

Organizm kobiety ciężarnej zmienia swoją gospodarkę wapniową, a także metabolizm witaminy D. Już we wczesnej ciąży u matki obserwuje się wzrost ekspresji nerkowej $1 \alpha$-hydroksylazy, co sprzyja syntezie kalcytriolu. Wzrost poziomu witaminy D jest wprost proporcjonalny do czasu trwania ciąży [73]. Syntetyzowana w organizmie matki witamina dostarczana jest do płodu poprzez łożysko $[74,75]$. Objawami niedoboru witaminy D w organizmie kobiety ciężarnej mogą być m.in. stan przedrzucawkowy, nadciśnienie czy cukrzyca ciężarnych. Ponadto Hollis udowodnił, że optymalny poziom witaminy D w trakcie ciąży przyczynia się do redukcji liczby powikłań, cięć cesarskich, a także nadciśnienia ciążowego [74]. Z kolei Liu udowodnił, że niedobór witaminy D w większości przypadków prowadzi do powstania stanu zapalnego łożyska, stanu zapalnego pochwy (co podwyższa ryzyko poronienia i porodu wcześniejszego), a także choroby przyzębia u matki [76]. Prowadzone są także badania, które pozwolą w przyszłości zastosować ocenę stężenia metabolitów witaminy D we wczesnych etapach ciąży jako predyktor rozwoju cukrzycy ciążowej [77].

Konsekwencją niedoboru witaminy D w organizmie ciężarnej jest jej niedobór w organizmie dziecka. Witamina D ma ogromny wpływ na rozwój szkieletu płodu, szkliwa zębów, a także w ogólnym rozwoju [78]. Prenatalny niedobór tego składnika może predysponować do rozwoju SM, astmy i atopii [79] oraz szeregu chorób metabolicznych [80].

\section{Witamina D a nowotwory}

Witamina D wykazuje działanie przeciwnowotworowe poprzez hamowanie proliferacji komórkowej, inicjację apoptozy, a także dzięki roli w angiogenezie, ekspresji białek adhezyjnych i procesach zapalnych. Powoduje zmniejszenie namnażania się komórek i wpływa na ich końcowe różnicowanie [81]. Szerokie spektrum działania kalcytriolu wiąże się z występowaniem genu VDR w wielu tkankach i narządach organizmu ludzkiego, m.in. w mózgu, jelicie grubym, sutku czy gruczole krokowym. Udowodniono, że osoby z deficytem witaminy $D$ chorują nawet 2 razy częściej na nowotwory jelita grubego, prostaty, trzustki, jajnika czy piersi [82]. Przy występowaniu niektórych nowotworów synteza 1 $\alpha$-hydroksylazy jest znacząco obniżona. Kompleks witaminy $D$ z jej receptorem ma za zadnie hamować cykl komórkowy na granicy faz G1/G0 [83]. Prawidłowy poziom witaminy $D$ koreluje u chorych onkologicznych z lżejszym przebiegiem, lepszym rokowaniem oraz mniejszą umieralnością i ryzykiem przerzutów [84, 85].

\section{Witamina D a cukrzyca}

Według najnowszych doniesień International Diabetes Federation z powodu cukrzycy cierpi aż 6\% ludzi w skali całego świata (425 milionów osób) [86]. Jeszcze większa grupa znajduje się w stanie przedcukrzycowym (prediabetes). Udowodniono, że deficyt witaminy D ma związek z rozwojem cukrzycy, zarówno typu 1, jak i 2 [87]. Komórki beta zlokalizowane na wyspach trzustkowych posiadają receptory dla witaminy $D$ oraz $1 \alpha$-hydroksylazę [88]. Suplementacja powoduje poprawę tolerancji glukozy, a także skutkuje ograniczeniem insulinooporności $[89,90]$. W sytuacji niedoboru witaminy D organizm ogranicza wydzielanie insuliny, co może być podstawową przyczyną choroby, mówi się także o pośredniej zależności między witaminą D a insuliną witamina D poprzez sygnalizację wapniową [91].

\section{Wnioski}

Witamina D odgrywa niezwykle ważną rolę w organizmie człowieka, leczwiedzanatentematjestwciążniekompletna. Jest czynnikiem kontrolującym syntezę licznych peptydów i białek, wykazano jej niepodważalny wpływ na różnicowanie, apoptozę i hamowanie proliferacji komórek oraz angiogenezę, niezwykle ważne obserwacje dotyczą jej działania immunomodulującego. Jej wielokierunkowe spektrum działania daje wiele możliwości terapeutycznych i stało się podstawą ogromnego marketingowego sukcesu tej witaminy.

Niestety, w populacji w skali światowej stwierdza się znaczne niedobory witaminy D, co przynajmniej w części przypadków wynika z nadwagi lub otyłości, siedzącego trybu życia i błędów dietetycznych. Kumulatywnie wiąże się to ze złym samopoczuciem i wpływa na szacowaną długość życia. Zwiększanie świadomości dotyczącej korzyści płynących z właściwej podaży oraz suplementacji wydaje się wręcz koniecznością.

\section{Oświadczenia}

Oświadczenie dotyczące konfliktu interesów

Autorzy deklarują brak konfliktu interesów.

Źródła finansowania

Autorzy deklarują brak źródeł finansowania. 
Piśmiennictwo

1. Goltzman D. Functions of vitamin $D$ in bone. Histochem Cell Biol. 2018; 149(4): 305-312. DOI: 10.1007/s00418-0181648-y.

2. Bikle DD. Extraskeletal actions of vitamin D. Ann N Y Acad Sci. 2016; 1376(1): 29-52. DOI: 10.1111/nyas.13219.

3. Ricca C, Aillon A, Bergandi L et al. Vitamin D Receptor Is Necessary for Mitochondrial Function and Cell Health. Int J Mol Sci. 2018; 19(6). pii: E1672. DOI: 10.3390/ijms19061672.

4. Jakobsen J, Knuthsen P. Stability of vitamin D in foodstuffs during cooking Food Chem. 2014; 148: 170-175. DOI: 10.1016/j. foodchem.2013.10.043.

5. Piersma A, Hessel E, Staal YC. Retinoic acid in developmental toxicology: Teratogen, morphogen and biomarker. Reprod Toxicol. 2017;72:53-61. doi:10.1016/j.reprotox.2017.05.014.

6. Marcinowska-Suchowierska E, Walicka M, Tałałaj M et al. Vitamin D supplementation in adults - guidelines. Endokrynol Pol. 2010; 61(6): 723-729.

7. Pludowski P. Practicalguidelines for the supplementation of vitamin $D$ and the treatment of deficits in Central Europe recommendedvitamin $D$ intakes in the generalpopulation and groupsatrisk of vitamin D deficiency. Endokrynol Pol. 2013; 64(4): 27-319.

8. Kennel $K$, Drake M, Hurley D. Vitamin D deficiency in adults: when to test and how to treat. Mayo Clin Proc. 2010; 85(8): 752-757. DOI: $10.4065 / \mathrm{mcp} .2010 .0138$.

9. Zdrojewicz Z, Chruszczewska E, Miner M. Wpływ witaminy D na organizm człowieka. MedRodz. 2015; 2(18): 61-66.

10. Płudowski P, Kryśkiewicz E, Karczmarewicz E. Zasady suplementacji i standardy oceny zaopatrzenia organizmu w witaminę D w świetle jej działania plejotropowego. Postępy Nauk Med. 2012; 25: 265-272.

11. Jones $G$. Vitamin D safety: its mechanisms and application. Stand. Med. 2012; 9: 605-609.

12. Ross A, Manson J, Abrams S et al. The 2011 report on dietaryreferenceintakes for calcium and vitamin $D$ from the Institute of Medicine: whatcliniciansneed to know. J. Clin. Endocrinol. Metab. 2011; 96: 53-58.

13. Turpeinen U, Hohenthal U, Stenman U-H. Determination of 25-Hydroxyvitamin D in Serum by HPLC and Immunoassay. Clinical Chemistry. 2003; 49(9): 1521-1524.

14. Pal M, Datta S, Pradhan A et al. Comparison between different methods of estimation of vitamin D. Advances in Biological Chemistry, 2013; 3: 501-504. DOI: 10.4236/abc.2013.35054.

15. Bartoszewicz Z, Kondracka A, Jaźwiec J et al. Czy umiemy wiarygodnie mierzyć stężenia klinicznie ważnych metabolitów witaminy $D$ ? Problemy i ich konsekwencje. Endokrynol Pol. 2013; 64(2): 22-30.

16. Kempisty A, Lewandowska A, Kuś J. Disturbances of calcium metabolism and vitamin $\mathrm{D}$ supplementation in sarcoidosis two-way street. Pol Merkur Lekarski. 2018; 44(261): 147-149.

17. Selvaraj P, Prabhu Anand S, Harishankar M et al.Plasma 1,25 dihydroxy vitamin D3 level and expression of vitamin d receptor and cathelicidin in pulmonary tuberculosis. J Clin Immunol. 2009; 29(4): 470-8. DOI: 10.1007/s10875-009-9277-9.

18. Cashman K, Dowling K, Škrabáková Z et al. Vitamin D deficiency in Europe: pandemic? Am J Clin Nutr. 2016; 103(4): 1033-1044. DOI: 10.3945/ajcn.115.120873.

19. Saggese $G$, Vierucci F, Prodam F et al. Vitamin D in pediatric age: consensus of the Italian Pediatric Society and the Italian Society of Preventive and Social Pediatrics, jointly with the Italian Federation of Pediatricians. Ital J Pediatr. 2018; 44(1): 51. DOI: 10.1186/s13052-018-0488-7.

20. Pludowski P, Jaworski M, Niemirska K et al. Vitamin D status, body composition and hypertensive target organ da- mage in primary hypertension. J Steroid Biochem Mol Biol. 2014;144:180-184.

21. Miratashi Yazdi S, Abbasi M, Miratashi Yazdi S.M. Epilepsy and vitamin D: a comprehensive review of current knowledge. Rev Neurosci. 2017: (2): 185-201. DOI: 10.1515/revneuro-2016-0044.

22. Marcinowska-Suchowierska E, Walicka M, Tałałaj M et al. Vitamin D supplementation in adults - guidelines. Endokrynol Pol. 2010; 61(6): 723-729.

23. Kimlin M, Olds W, Moore M. Who, what, where and when; influences on cutaneous Vitamin D synthesis. Prog Biophys Mol Biol. 2006; 92: 17-25.

24. Hathcock J, Shao A, Vieth R et al. Risk assessment for vitamin D. Am J Clin Nutr. 2007; 85(1): 6-18.

25. Armas L, Dowell S, Akhter M et al. Ultraviolet-B radiation increases serum 25 -hydroxyvitamin D levels: the effect of UVB dose and skin color. J. Am. Acad. Dermatol. 2007; 57: 588-593.

26. Maetani M, Maskarinec G, Franke A, Cooney R.V. Association of lepton, 25-hydroxyvitamin $D$, and parathyroid hormone In women. Nutr. Cancer. 2009; 61: 231-225.

27. Cheng J, Levine $M$, Bell $N$ et al. Genetic evidence that the human CYP2R1 enzyme is a key vitamin D 25-hydroxylase. Proc Natl. Acad. Sci. USA. 2004; 101: 7711-7715.

28. Deluca H, Cantorna M. Vitamin D: its role and uses in immunology. FASEB J. 2001;15:2579-2585.

29. Toniato $E$, Spinas E, Saggini A et al. Immunomodulatory effects of vitamin D on skin inflamation. J Biol Regul Homeost Agents. 2015; 29(3): 563-567.

30. Cantorna M, Hullett D, Redaelli C et al. 1,25-Dihydroxyvitamin D3 prolongs graft survival without compromising host resistance to infection or bone mineral density. Transplantation. 1998; 66(7): 828-831.

31. MorimotoS, Kumahara Y. A patient with psoriasis cured by 1 alphahydroxyvitamin D3. Med J Osaka Univ. 1985; 35(3-4): 51-54.

32. Holick MF. Clinical efficacy of 1,25-dihydroxyvitamin D3 and its analogues in the treatment of psoriasis. Retinoids. 1998; 14: 12-17.

33. Searing D, Leung D. Vitamin $D$ in atopic dermatitis, asthma and allergic diseases. Immunol Allergy Clin North Am. 2010; 30(3): 397-409. DOI: 10.1016/j.iac.2010.05.005.

34. Hata T, Audish D, Kotol P et al. A randomized controlled double-blind investigation of the effects of vitamin $D$ dietary supplementation in subjects with atopic dermatitis. J Eur Acad Dermatol Venereol. 2014; 28(6): 781-9. DOI: 10.1111/ jdv. 12176 .

35. Faridar A, Eskandari G, Sahraian M et al. Vitamin D and multiple sclerosis: a critical review and recommendations on treatment. Acta Neurol Belg. 2012; 112(4): 327-333. DOI: 10.1007/ s13760-012-0108-z.

36. Mirzaei F, Michels K, Munger K et al. Gestational vitamin D and the risk of multiple sclerosis in offspring. Ann Neurol. 2011; 70(1): 30-40. DOI: 10.1002/ana.22456

37. Soilu-Hänninen $M$, Aivo J, Lindström B et al. A randomised, double blind, placebo controlled trial with vitamin D3 as an add on treatment to interferon $\beta-1 \mathrm{~b}$ in patients with multiple sclerosis. J. Neurol. Neurosurg. Psychiatry. 2012; 83: 565-570.

38. Grazio $S$, Naglić $Đ$, Anić B et al. Vitamin D serum level, disease activity and functional ability in different rheumatic patients Am. J. Med. Sci. 2015; 349: 46-49.

39. Tetlow $L$, Woolley D. The effects of $1 \alpha, 25$-dihydroxyvitamin D3 on matrix metalloproteinase and prostaglandin E2 production by cells of the rheumatoid lesion. Arthritis Res. 1999; 1: 63-70.

40. Sharma R, Saigal R, Goyal L et al. Estimation of vitamin D levels in rheumatoid arthritis patients and its correlation with the disease activity. J Assoc Physicians India. 2014; 62 (8): 678-81. 
41. Meena N, Singh Chawla S, Garg R et al. Assessment of Vitamin $\mathrm{D}$ in Rheumatoid Arthritis and Its Correlation with $\mathrm{Di}$ sease Activity. J Nat Sci Biol Med. 2018; 9(1): 54-58. DOl: 10.4103/jnsbm.JNSBM_128_17.

42. DeLuca HF. Overview of general physiologic features and functions of vitamin D. Am. J. Clin. Nutr. 2004; 80: 1689S-1696S.

43. Tyagi $G$, Singh $P$, Varma-Basil $M$ et al. Role of Vitamins $B, C$ and $D$ in the fight against tuberculosis. Int J Mycobacteriol. 2017; 6(4): 328-332. DOI: 10.4103/ijmy.ijmy 8017.

44. Brehm J, Schuemann B, Fuhlbrigge A et al. Childhood Asthma Management Program Research Group.: Serum vitamin $D$ levels and severe asthma exacerbations in the childhood. Asthma Management Program study. J Allergy Clin Immun 2010; 126: 52-58.

45. Xystrakis E, Kusumakar S, Boswell S et al. Reversing the defective induction of IL-10 secreting regulatory t cells in glucocotricoid-resistant asthma patients. J Clin Inves, 2006; 116: 146-155.

46. Ginde A, Mansbach J, Camargo C. Association between serum 25-hydroxyvitamin $D$ level and upper respiratory tract infection. In the Third National Health and Nutrition Examination Survey. Arch Intern Med. 2009; 169: 384-390.

47. Van Wetering S, Sterk P, Rabe K et al. Defensins: key players or bystanders in infection, injury, and repair in the lung? J Allergy Clin J. 1999; 104: 1131-1138.

48. Grey V, Atkinson S, Drury D et al. Prevalence of low bone mass and deficiencies of vitamins $D$ and $K$ in pediatric patients with cystic fibrosis from 3 Canadian centers. Pediatrics. 2008; 122: 1014-1020.

49. Perzanowska-Brzeszkiewicz K, Marcinowska-Suchowierska E Witamina $D$ a choroby przewodu pokarmowego. Postępy Nauk Med. 2012; 25: 247-251.

50. Socha P. Witamina D w chorobach przebiegających z zaburzeniami wchłaniania (mukowiscydoza, cholestaza, nieswoiste zapalenie jelit). Stand. Med. 2012; 9: 655-658.

51. Saarnio $E$, Pekkinen $M$, Itkonen $S$ et al. Low free 25 hydroxyvitamin $\mathrm{D}$ and high vitamin $\mathrm{D}$ binding protein and parathyroid hormone in obese Caucasians. A complex association with bone? PLoS One. 2018; 13(2):ne0192596. DOI: 10.1371/journal.pone. 0192596.

52. Kamei $Y$, Kawada T, Kazuki R et al. Vitamin D receptor gene expression is up-regulated by 1,25-dihy $\neg$ droxyvitamin D3 in 3T3-L1 preadipocytes. Biochem. Biophys. Res. Commun. 1993; 193: 948-955.

53. Abbas M.A. Physiological functions of Vitamin $D$ in adipose tissue. J Steroid Biochem Mol Biol. 2017; 165(Pt B): 369-381. DOI: $10.1016 / j$.jsbmb.2016.08.004.

54. Kong J, Chen Y, Zhu G et al. 1,25-dihydroxyvitamin D3 upregulates leptin expression in mouse adipose tissue. J. Endocrinol. 2013; 216: 265-271.

55. Wąsowski M, Czerwińska E, Marcinowska-Suchowierska E Otyłość - stan predysponujący do niedoborów witaminy D. Postępy Nauk Med. 2012; 25: 258-264.

56. Kheiri B, Abdalla A, Osman M et al. Vitamin D deficiency and risk of cardiovascular diseases: a narrative review. Clin Hypertens. 2018; 24: 9. DOI: 10.1186/s40885-018-0094-4.

57. Christakos S, Hewison M, Gardner D et al. Vitamin D: beyond bone. Ann. N.Y. Acad. Sci. 2013; 1287: 45-58.

58. Verhave $G$, Siegert C. Role of vitamin D in cardiovascular disease. Neth J Med. 2010; 68(3): 113-118.

59. Mehta V, Agarwal S. Does Vitamin D Deficiency Lead to Hypertension? Cureus. 2017; 9(2): e1038.

60. Mirhosseini N, Knaus S, Bohaychuk K et al. Both high and low plasma levels of 25-hydroxy vitamin D increase blood pressure in a normal rat model. Br J Nutr. 2016; 116(11): 1889-1900. DOI: $10.1017 /$ S0007114516004098.
61. Li YC. Vitamin D regulation of the renin-angiotensin system J. Cell. Biochem., 2003; 88: 327-331.

62. Ish-Shalom M, Sack J, Vechoropoulos M et al. Low-dose calcitriol decreases aortic renin, blood pressure, and atherosclerosis in apoe-null mice. J Atheroscler Thromb. 2012; 19(5): 422-434.

63. Kienreich $\mathrm{K}$, Grubler M, Tomaschitz A et al. Vitamin D, arterial hypertension \& cerebrovascular disease. Indian J Med Res. 2013; 137(4): 669-679.

64. Pilz S, Gaksch M, O'Hartaigh B et al. The role of vitamin D deficiency in cardiovascular disease: where do we stand in 2013? Arch Toxicol. 2013; 87(12): 2083-2103. DOI: 10.1007/ s00204-013-1152-z.

65. Saliba W, Awad K, Ron G et al. The Effect of Vitamin D Supplementation on Thrombin Generation Assessed by the Calibrated Automated Thrombogram. Clin Appl Thromb Hemost. 2016; 22(4): 340-345. DOI: 10.1177/1076029614556745.

66. Khademvatani K, Seyyed-Mohammadzad M, Akbari M et al. The relationship between vitamin D status and idiopathic lower-extremity deep vein thrombosis. Int J Gen Med. 2014; 7 303-309. DOI: 10.2147/IJGM.S64812.

67. Newmark H, Newmark J. Vitamin D and Parkinson's disease a hypothesis. Mov Disord. 2007; 22: 461-468.

68. Wali S, Alsafadi S, Abaalkhail B et al. The Association Between Vitamin D Level and Restless Legs Syndrome: A Population-Based Case-Control Study. J Clin Sleep Med. 2018; 14(4): 557-564. DOI: 10.5664/jcsm.7044.

69. Trinko J, Land B, Solecki W et al. Vitamin D3: A Role in Dopamine Circuit Regulation, Diet-Induced Obesity, and Drug Consumption. eNeuro. 2016;3(2). pii: ENEURO.0122-15.2016. DOI: 10.1523/ENEURO.0122-15.2016

70. Ouma S, Suenaga M, Bölükbaşı Hatip F et al. Serum vitamin D in patients with mild cognitive impairment and Alzheimer's disease. Brain Behav. 2018; 8(3): e00936. DOI: 10.1002/brb3.936.

71. Bertone-Johson E, Powers S, Spangler L et al. Vitamin D intake from foods and suppplements and depressive symptoms in a diverse population of older women. Am J Clin Nutr. 2011: 94: 1104-1112.

72. Trujillo J, Vieira M, Lepsch J et al. A systematic review of the associations between maternal nutritional biomarkers and depression and/or anxiety during pregnancy and postpartum. J Affect Disord. 2018; 232: 185-203. DOI: 10.1016/j. jad.2018.02.004

73. Kovacs C, Kronenberg H. Maternal-fetal calcium and bone metabolism during pregnancy, puerperium, and lactation. Endocrine Reviews. 1997; 18(6): 832-872.

74. Hollis B, Johnson D, Hulsey T.C et al. Vitamin D supplementation during pregnancy: Double-blind, randomized clinical trial of safety and effectiveness. J Bone Miner Res. 2011; 26: 2341-2357.

75. Noff D, Edelstein S. Vitamin D and its hydroxylated metabolites in the rat. Placental and lacteal transport, subsequent metabolic pathways and tissue distribution. Horm Res. 1978; 9 : 292-300

76. Liu N, Kaplan A, Lagishetty $V$ et al. Vitamin D and the regulation of placental inflammation. J Immunol. 2011; 186(10): 5968-5974.

77. Xu C, Ma H, Wang Y. Maternal Early Pregnancy Plasma Concentration of 25-Hydroxyvitamin D and Risk of Gestational Diabetes Mellitus. Calcif Tissue Int. 2018; 102(3): 280-286. DOI: 10.1007/s00223-017-0346-4.

78. Scholl T, Chen X. Vitamin D intake during pregnancy: association with maternal characteristics and infant birth weight. Early Hum Dev. 2009; 85(4): 231-234. 
79. Douros K, Boutopoulou B, Fouzas S et al. Asthma and Allergy "Epidemic" and the Role of Vitamin D Deficiency. Adv Exp Med Biol. 2017; 996: 169-183. DOI: 10.1007/978-3-31956017-5 14.

80. Blighe K, Chawes B, Kelly R.S et al. Vitamin D prenatal programming of childhood metabolomics profiles at age $3 \mathrm{y}$. Am J Clin Nutr. 2017; 106(4): 1092-1099. DOI: 10.3945/ajcn.117.158220.

81. Tagliabue E, Raimondi S, Gandini S. Vitamin D, cancer risk, and mortality. Adv Food Nutr Res. 2015; 75: 1-52.

82. Ferrer-Mayorga G, Larriba M, Crespo P et al. Mechanisms of action of vitamin $\mathrm{D}$ in colon cancer. J Steroid Biochem Mol Biol. 2018: pii: S0960-0760(18)30295-4. DOI: 10.1016/j. jsbmb.2018.07.002.

83. Moukayed M, Grant W.B. Molecular link between vitamin D and cancer prevention. Nutrients. 2013; 5: 3993-4021.

84. Barreto $S$, Neale R. Vitamin D and pancreatic cancer. Cancer Lett. 2015; 368(1): 1-6. DOI: 10.1016/j.canlet.2015.06.030.

85. Huang J, Dong C, Shao $S$ et al. Circulating 25-hydroxyvitamin $D$ level and prognosis of lung cancer patients: A systematic review and meta-analysis. Bull Cancer. 2017; 104(7-8): 675682. DOI: 10.1016/j.bulcan.2017.05.001.

86. IDF Diabetes Atlas 8th Edition: https://www.idf.org/e-library/epidemiology-research/diabetes-atlas.html.

87. Martin T, Campbell K. Witamina D a cukrzyca. Diabetologia po Dyplomie. 2011; 8(3): 21-25.
88. Bland R, Markovic D, Hills C et al. Expression of 25hydroxyvitamin D3-1 alpha-hydroxylase in pancreatic islets J Steroid Biochem Mol Biol. 2004; 121: 89-90.

89. He S, Yu S, Zhou Z et al. Effect of vitamin D supplementation on fasting plasma glucose, insulin resistance and prevention of type 2 diabetes mellitus in non-diabetics: A systematic review and meta-analysis. Biomed Rep. 2018; 8(5): 475-484 DOI: 10.3892/br.2018.1074.

90. Parekh D, Sarathi V, Shivane V.K et al. Pilot study to evaluate the effect of short-term improvement in vitamin $D$ status on glucose tolerance in patients with type 2 diabetes. Endocr Pract. 2010; 16: 600-660.

91. Pittas A, Lau J, Hu F.B et al. The role of vitamin D and calcium in type 2 diabetes: a systematic review and metaanalysis. J Clin Endo Metab. 2007; 92: 2017-2029.

Zaakceptowano do edycji: 15.12.2019 Zaakceptowano do publikacji: 15.02.2020

Adres do korespondencji:

Anna Piotrowska

al. Jana Pawła 1178

31-571 Kraków

e-mail: Anna.Piotrowska@awf.krakow.pl 